\title{
Evaluation of the Drought Stress Effects on Cotton Genotypes by Using Physiological and Morphological Traits
}

\author{
Abdel-Kader M.A. ${ }^{1}$, A. M. Esmail ${ }^{2}$, K.A. El Shouny ${ }^{3}$, M.F. Ahmed ${ }^{4}$ \\ ${ }^{1,2,3,4}$ Agronomy Department, Faculty of agriculture, Ain Shams Univ., Cairo, Egypt
}

\begin{abstract}
Drought stress is the major environmental factor that negatively impacts cotton yield throughout the world. Thus, there is a need for a protocol to offer new opportunities for improving drought tolerance in cotton. By understanding the correlation between yield and morphological traits (root length, shoot length, root/shoot ratio), and physiological traits (relative water content (RWC), electrolyte leakage percentage (EL\%), membrane stability index (MSI\%), Chlorophyll a, chlorophyll b, total chlorophyll, chlorophyll a/b ratio, chlorophyll stability index (CSI)), we can develop efficient screening method able to screen large amounts of plant material in the shortest time possible. In the current study, 21 cotton genotypes (6 parents and their $15 F_{1}$ crosses) were evaluated under two irrigation treatments i.e., $100 \%$ ETc, $1269 \mathrm{~mm} / \mathrm{season}$ (normal) and $60 \%$ ETc, $761 \mathrm{~mm} / \mathrm{season}$ (drought). The morphological and physiological traits were studied. Also, correlation between yield and physiological and morphological traits were determined. The results revealed high significant difference among genotypes for all the studied physiological and morphological traits under normal and drought treatments. Although all studied traits in all genotypes were significantly affected by drought but some genotypes such as Tamcot $C$. E. $x$ Deltapine, Giza 90x (Giza 90X Australian) and Giza 80x Deltapine showed drought tolerance by maintaining the highest values of root length, shoot length, root/shoot ratio, RWC, MSI, Chlorophyll a, b, total chlorophyll, chlorophyll a/b ratio, CSI and lowest values of EL\% under drought stress. Yield was correlated with each of the morphological and physiological traits under normal and drought conditions. Therefore, it could be concluded that the morphological and physiological traits could be used as selection criteria for high yield under drought stress.
\end{abstract}

Keywords: Cotton Genotypes, Drought, Yield, Correlation, Morphological and Physiological traits

\section{Introduction}

Drought is the most important factor limiting crop productivity around the world. Among the environmental stresses, drought is one of the most adverse factors for plant growth and productivity (Reddy $\boldsymbol{e t}$ al., 2004 and Makbul $\boldsymbol{e t}$ al., 2011) and is a complex physical- chemical process (Apel and Hirt, 2004 and Moaveni, 2011). Cotton production is adversely affected by water stress (Pettigrew, 2004; Dağdelen et al., 2006 and Basal et al., 2009). Insufficient soil water content during the sensitive growth stages such as the blooming, flowering and fruit-setting stages can lead to a reduced plant height, fresh and dry weight, number of fruiting branches, boll shedding, developed bolls and seeds, seed cotton yield and yield attributes (Yazar et al., 2002 ; Pettigrew, 2004 and Aujla et al., 2005).

Root length of plants subjected to low levels of water content registered high significant increases in root length above those of plants irrigated with high water content (Cook and El-Zik, 1992; Prior et al., 1997; Chaitante et al., 2000 and Abdalla and El-Khoshiban, 2007) and be deeper under drought conditions than irrigated environment (Hurd and Spratt, 1975; Pace et al., 1999; Howard et al., 2001; Basal et al., 2003; Kamara et al., 2003; Rizza et al., 2004; Moinuddin et al., 2005 and Hufstetler et al., 2007). Plant growth is one of the most drought-sensitive physiological processes due to the reduction in turgor pressure (Taiz and Zeiger, 2006) and increasing the severity and duration of drought caused decline in shoot length (Schuzendubel et al., 2002 and Abdalla and ElKhoshiban, 2007). The Root/shoot length ratio is adaptive mechanism in response to water deficit, it is considered an important indicator for the ability of a genotype to tolerate drought stress. Root/shoot ratio increased under water stress condition to facilitate water absorption (Lambers et al., 1998).

Relative water content (RWC) is a measure of the amount of water present in the leaf tissue. High RWC under drought stress conditions would be preferable to maintain water balance. Higher RWC in leaf has been reported as selection criteria to breed plants tolerate to drought stress (Clarke and McCaig, 1982; Malik et al. 1999 and Rahman et al., 2000). Biological membranes are the first target of many abiotic stresses. Membrane stability index (MSI) is reciprocal to cell electrolyte leakage (EL) and both of them are physiological indices widely used for evaluating drought tolerance (Premachandra et al., 1991). The drought stress lead to increase in electrolyte leakage in plant leaves (Sairam and Saxena 2000 and Sibet and Birol 2007). Cell membrane stability index was found to be higher in tolerant genotypes than susceptible genotypes under stress conditions (Dhanda et al., 2004; Arvin and Donnelly, 2008 and Collado et al., 2010). Chlorophyll contents as chlorophyll 'a' and chlorophyll 'b' plays a vital role in photosynthetic process which ultimately increases crop growth and yield (Taiz and Zieger, 2006). Drought stress is one of the factors affecting chlorophyll 'a', 'b', total chlorophyll and a/b ratio (Ashraf et al., 1994; Havaux, 1998; Delfine et al., 1998; Ashraf and Ahamad 2000; Kiani et al., 2008; Massacci et al., 2008 and Hamayun et al., 2010). By studying the effect of drought stress on chlorophyll, it was found that drought stress had decreased chlorophyll 'a', 'b', total chlorophyll and a/b ratio (Araus et al., 1998; Anjum et al., 2003; Kiani et 


\section{International Journal of Science and Research (IJSR) ISSN (Online): 2319-7064 \\ Index Copernicus Value (2013): 6:14 | Impace Factor (2014)! 5:611}

al., 2008; Massacci et al., 2008 and Hamayun et al., 2010). Chlorophyll stability index (CSI) is the ratio between total chlorophyll under drought to total chlorophyll under normal irrigation. High CSI is an indicator to drought tolerance. So, Patil et al. (2011) revealed that CSI was higher in drought tolerant genotypes compared to other susceptible genotypes. The key to an efficient screening method is the ability to screen large amounts of plant material in the shortest time possible. Effective screening methods must evaluate plant performance at critical developmental stages (Johnson, 1980). The screening method must be incorporated into plant breeding programs to facilitate meaningful genetic improvement. Plant physiological and morphological traits are now incorporated into the breeding program by using them as selection criteria relevant to the designated plant ideotype and subsequent plant performance in the stress environment. Breeder offers a great potential for the improvement of breeding efficiency towards drought stress (De Ronde, et al., 2000). Morphology and Physiology as screening criteria are able to measure various plant characteristics that correlated with drought tolerance, such as root length, shoot length, root/shoot ratio, relative water content, electrolyte leakage percentage, membrane stability index, Chlorophyll a, chlorophyll b, total chlorophyll, chlorophyll $\mathrm{a} / \mathrm{b}$ ratio, chlorophyll stability index.

\section{Material and methods}

Plant material: Six divergent parental cotton genotypes and their $\mathrm{F}_{1}$ crosses were used in this investigation to study drought tolerance in cotton (Gossypium spp.). The parental cotton genotypes including two exotic varieties belong to $\mathrm{G}$. hirsutum L., namely; Deltapine and Tamcot Camd E. (Tamcot C.E.), and four local Egyptian cultivars namely; Giza 80, Giza 86, Giza 90, Giza 90 x Australian (new promising cotton hybrid) belong to G. barbadense L. Pure seeds of these varieties were supplied by Cotton Breeding Section, Cotton Research Institute, Agriculture Research Center at Giza, Egypt. The genotypes, pedigree and characterization of these genotypes are presented in Table 1.

Table 1: The names, pedigree and the main characteristics of six cotton genotypes used as parents in the present study.

\begin{tabular}{|c|c|c|}
\hline Genotypes & Pedigree & Characteristics \\
\hline Giza 80 & G.66 x G. 73 & $\begin{array}{l}\text { A long staple cotton variety, early maturity, high yield, good yarn, high lint \% and tolerance to high } \\
\text { temperature and cultivated in upper Egypt }\end{array}$ \\
\hline Giza 86 & G.75 x G.81 & $\begin{array}{c}\text { A long staple cotton variety, characterized by late maturity, high yield and strong lint and cultivated } \\
\text { in Delta }\end{array}$ \\
\hline Giza 90 & Dandara x G.83 & $\begin{array}{l}\text { A long staple cotton variety, early maturity, high yield, good yarn, high lint } \% \text { and tolerance to high } \\
\text { temperature and cultivated in upper Egypt }\end{array}$ \\
\hline $\begin{array}{l}\text { Giza 90X } \\
\text { Australian }\end{array}$ & $\begin{array}{c}\text { G. } 90 \mathrm{x} \\
\text { Australian }\end{array}$ & $\begin{array}{l}\text { A long staple cotton variety, characterized by high yielding, early maturity, high lint } \% \text {, resistance to } \\
\text { fuzariam and tolerance to high temperature. }\end{array}$ \\
\hline Deltapine & Upland cotton & High yield, high lint \%, early maturity, fiber length ranged from $28-30$. \\
\hline amcot Camd E. & Upland cotton & High yield, high lint \%, early maturity, fiber length ranged from $28-30$. \\
\hline
\end{tabular}

Experimental Site: The six parents were crossed in all possible combinations, excluding reciprocals in 2012 growing season at the farm of Fac., Agric., Ain-Shams univerisity, Shoubra El-Kheima, Qalyubia governorate, Egypt. to obtain a total of $15 \mathrm{~F}_{1}$ hybrids. In 2013 growing season, the six parents and their $15 \mathrm{~F}_{1}$ 's (21 genotypes) were planted on $2^{\text {nd }}$ of April and evaluated for drought tolerance in sandy soil conditions in a private farm at Shebin ElKanater, Qalyubia governorate, Egypt.

Water treatments: Two separate experiments were carried out one for each water treatment. The first water treatment was irrigation at 100\% Etc, $1269 \mathrm{~mm} / \mathrm{season}$ which represent normal water treatment, and the second was irrigation at $60 \%$ Etc, $761 \mathrm{~mm} /$ season which represent drought stress. The total amount of irrigation water was calculated according to Penman-Montieth method (Allen $\boldsymbol{e t}$ al., 1996), Penman-Monteith method gives more consistently accurate ETo estimates than other ETo methods. Drip irrigation system was installed; the drip lateral had emitters spaced $30 \mathrm{~cm}$ apart with a nominal discharge of 4 liters/h. Blocks were irrigated using an electric timer with appropriate run times to give the desired application of water.

Experimental design: The experimental design was arranged in a randomized complete blocks with three replicates. Ridges were $6 \mathrm{~m}$ long and $120 \mathrm{~cm}$ width and seeds were planted on the both ridge sides, each genotype on one side. Hills were spaced at $25 \mathrm{~cm}$ on the ridge side with two seedlings per hill.

Soil preparation: During land preparation, the soil was fertilized by $30 \mathrm{~m}^{3}$ compost. Phosphorous fertilizer as

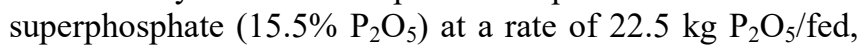
nitrogen fertilizer as ammonium nitrate $(33.5 \% \mathrm{~N})$ at a rate of $90 \mathrm{~kg} \mathrm{~N} / \mathrm{fed}$, and potassium fertilizer as potassium sulfate $\left(48 \% \mathrm{~K}_{2} \mathrm{O}\right)$ at a rate of $50 \mathrm{~K}_{2} \mathrm{O} /$ fed. were applied in five equal doses with irrigation water as recommended by Cotton Research Institute, Agriculture Research Center at Giza, Egypt. Picking of experiments was carried out on $26^{\text {th }}$ of October.

\section{Measurements}

After 60 days from sowing (blooming stage), ten plants were randomly selected from each replicate and the following parameters were determined;

\section{Morphological traits:-}

1) Root length: plants were cultivated in plastic tubes $75 \mathrm{~cm}$ tall x $12 \mathrm{~cm}$ wide and filled with fine sand (Riaz et al., 2013),

2) Shoot length,

3) Root/shoot ratio.

Physiological traits:-

1) Relative water content (RWC\%) (Weatherley, 1950),

\section{Volume 4 Issue 11, November 2015}


2) Electrolye leakage (EL\%) (Arora et al. 1992),

3) Membrane stability index (MSI) (Premachandra et al., 1990),

4) Chlorophyll a ( mg g-1 FW) (Hiscox and Israelstam, 1979),

5) Chlorophyll b ( mg g-1 FW) (Hiscox and Israelstam, 1979),

6) Total Chlorophyll ( mg-1 g FW) (Hiscox and Israelstam, 1979),

7) Chlorophyll $\mathrm{a} / \mathrm{b}$ ratio,

8) Chlorophyll stability index: determined as the ratio between total chlorophyll under drought to total chlorophyll under normal irrigation.

Seed cotton yield, at maturity ten plants were randomly selected from each replicate.

Statistical analysis: Analysis of variance and the expectations of mean squares for single and combined data were performed according to Gomez and Gomez (1984). Differences between means were tested using the least significant difference (L.S.D.) test according Waller and Duncan (1969) at the 5\% level of probability. Correlation coefficients between any two characters were performed as described by Mode and Rhobinson, (1959) and modified by Singh and Narayanan, (1993).

\section{Results and Discussion}

\section{Morphological traits}

Data presented in Table 2 indicate mean performance of morphological traits under normal and drought treatments. Regarding root length, the data show that the root length significantly increased by decreasing water treatment, it reached to its maximum length by drought treatment and its minimum length under normal treatment. The results indicate that water stress treatment had positive effect on root length. The highest root length was obtained from Deltapine, $\mathrm{P} 5 \mathrm{xP} 6$ and $\mathrm{P} 2 \mathrm{xP} 4$ under normal water and $\mathrm{P} 5 \mathrm{xP} 6$, $\mathrm{P} 3 \times \mathrm{P} 4$ and $\mathrm{P} 1 \times \mathrm{P} 6$ under drought. Combined analysis results show that $\mathrm{P} 5 \mathrm{xP} 6$ produced longest roots under normal and drought treatments. The root length of plants subjected to low levels of water content registered high significant increase in root length above those plants irrigated with high water content, such increase in linear growth of roots is attributed to either the increase in the gibberellins and cytokinin contents or to the ability of roots to branch and elongate quickly in an attempt to reach deeper levels to absorb its needs from underground water which thus enable plants to survive properly irrespective of water stress (Zhong and Lauchli, 1993; Rizza et al., 2004; Mahajan and Tuteja, 2005; Moinuddin et al., 2005; Abdalla and El-Khoshiban, 2007; Hufstetler et al., 2007 and Afshari et al., 2011).

Shoot length increased by increasing the water treatment Table 2, it reached its minimum length by subjecting plants to normal irrigation (Pace et al., 1999; Basal et al., 2003 and Abdalla and El-Khoshiban, 2007). Significant differences among genotypes under both water treatments were observed. The longest shoots were recorded by the genotypes $\mathrm{P} 1 \times \mathrm{P} 3, \mathrm{P} 3 \times \mathrm{P} 6$ and $\mathrm{P} 3 \times \mathrm{P} 4$ under normal treatment and $\mathrm{P} 3 \times \mathrm{P} 4, \mathrm{P} 5 \mathrm{xP} 6$ and $\mathrm{P} 1 \mathrm{xP} 5$ under drought stress. Combined analysis results reveal that the genotypes $\mathrm{P} 3 \mathrm{xP} 4$ and P5xP6 maintained the longest shoots in both water treatments. Basal et al. (2003); Taiz and Zeiger (2006) and Abdalla and El-Khoshiban (2007) declared that increase the severity and duration of drought resulted in decline in shoot length. Such decrease in shoot elongation in response to drought may be to decrease in cell elongation resulting from water shortage and/or due to blocking up of xylem and phloem vessels (Abdalla and El-Khoshiban 2007).

Data presented in Table 2 indicate the root/ shoot ratio. Root /shoot ratio increased by decreasing water treatment. Under normal irrigation, it's found that Tamcot C.E., Deltapine, $\mathrm{P} 2 \mathrm{xP} 4$ and $\mathrm{P} 5 \mathrm{xP} 6$ recorded the highest performance in comparison with the others. Under drought, the genotypes Tamcot C.E., Deltapine and P2xP6 gave highest performance. Combined analysis reported that Deltapine and Tamcot C.E. maintained highest performances under the two water treatments. Root/shoot ratio increased under water stress condition to facilitate water absorption and increased in drought tolerant

genotypes under drought (Lambers et al., 1998; Pace et al., 1999; Kumar 2010; Shah et al., 2011 and Sumartini et al., 2013). 


\section{International Journal of Science and Research (IJSR) \\ ISSN (Online): 2319-7064 \\ Index Copernicus Value (2013)! 6:14 | Impact Facter (2014)! 5:611}

Table 2: Mean performance of cotton genotypes for morphological traits under normal (N) and drought (D) treatments

\begin{tabular}{|c|c|c|c|c|c|c|c|c|c|}
\hline \multirow[b]{2}{*}{ Genotypes } & \multicolumn{3}{|c|}{ Root length $(\mathrm{cm})$} & \multicolumn{3}{|c|}{ Shoot length $(\mathrm{cm})$} & \multicolumn{3}{|c|}{ Root/Shoot ratio } \\
\hline & $\mathrm{N}$ & $\mathrm{D}$ & Combined & $\mathrm{N}$ & D & Combined & $\mathrm{N}$ & $\mathrm{D}$ & Combined \\
\hline Giza $80(\mathrm{P} 1)$ & 23.77 & 43.68 & 33.72 & 42.37 & 37.32 & 39.84 & 0.57 & 1.18 & 0.87 \\
\hline Giza 86 (P2) & 19.95 & 33.72 & 26.83 & 41.63 & 32.73 & 37.18 & 0.48 & 1.03 & 0.76 \\
\hline Giza $90(\mathrm{P} 3)$ & 21.12 & 43.83 & 32.47 & 52.57 & 37.62 & 45.09 & 0.41 & 1.17 & 0.79 \\
\hline Giza 90 x Australian (P4) & 31.78 & 38.24 & 35.01 & 47.9 & 35.93 & 41.92 & 0.67 & 1.08 & 0.87 \\
\hline Tamcot C. E. (P5) & 26.48 & 45.66 & 36.07 & 31.11 & 24.81 & 27.96 & 0.88 & 1.84 & 1.36 \\
\hline Deltapine (P6) & 42.51 & 34.26 & 38.38 & 48.62 & 21.5 & 35.06 & 0.88 & 1.6 & 1.24 \\
\hline Mean & 27.6 & 39.9 & 33.75 & 44.03 & 31.65 & 37.84 & 0.65 & 1.32 & 0.98 \\
\hline $\mathrm{P} 1 \mathrm{xP} 2$ & 28.3 & 33.63 & 30.96 & 53.85 & 33.1 & 43.47 & 0.53 & 1.02 & 0.77 \\
\hline $\mathrm{P} 1 \mathrm{xP} 3$ & 22.26 & 40.97 & 31.61 & 58.63 & 38.69 & 48.66 & 0.38 & 1.06 & 0.72 \\
\hline $\mathrm{P} 1 \mathrm{xP} 4$ & 19.48 & 43.69 & 31.59 & 52.69 & 40.48 & 46.59 & 0.37 & 1.08 & 0.73 \\
\hline P1xP5 & 24.47 & 45.84 & 35.16 & 53.94 & 46.87 & 50.4 & 0.48 & 0.98 & 0.73 \\
\hline P1xP6 & 26.86 & 52.87 & 39.87 & 46.03 & 44.43 & 45.23 & 0.59 & 1.19 & 0.89 \\
\hline $\mathrm{P} 2 \mathrm{xP} 3$ & 28.09 & 29.8 & 28.94 & 50.24 & 32.56 & 41.4 & 0.56 & 0.92 & 0.74 \\
\hline $\mathrm{P} 2 \mathrm{xP} 4$ & 33.58 & 29.78 & 31.68 & 41.53 & 34.3 & 37.91 & 0.82 & 0.87 & 0.84 \\
\hline $\mathrm{P} 2 \mathrm{xP5}$ & 25.89 & 41.12 & 33.51 & 43.74 & 42.14 & 42.94 & 0.6 & 0.98 & 0.79 \\
\hline $\mathrm{P} 2 \mathrm{xP} 6$ & 23.05 & 43.74 & 33.39 & 38.63 & 28.5 & 33.57 & 0.6 & 1.54 & 1.07 \\
\hline $\mathrm{P} 3 \mathrm{xP} 4$ & 22.28 & 55.83 & 39.06 & 55.23 & 49.5 & 52.37 & 0.48 & 1.01 & 0.75 \\
\hline $\mathrm{P} 3 \mathrm{xP5}$ & 26.02 & 30.17 & 28.1 & 40.44 & 24.9 & 32.67 & 0.65 & 1.22 & 0.94 \\
\hline P3xP6 & 19.54 & 54.54 & 37.04 & 56.81 & 44.14 & 50.47 & 0.35 & 1.24 & 0.8 \\
\hline $\mathrm{P} 4 \mathrm{xP5}$ & 28.43 & 37.32 & 32.87 & 37.73 & 29.09 & 33.41 & 0.75 & 1.29 & 1.02 \\
\hline $\mathrm{P} 4 \mathrm{xP} 6$ & 27.86 & 44.21 & 36.03 & 38.29 & 34.15 & 36.22 & 0.73 & 1.3 & 1.01 \\
\hline $\mathrm{P} 5 \mathrm{xP} 6$ & 36.11 & 55.59 & 45.85 & 49.46 & 46.74 & 48.1 & 0.78 & 1.13 & 0.95 \\
\hline Mean & 26.15 & 42.61 & 34.38 & 47.82 & 37.97 & 42.89 & 0.58 & 1.12 & 0.85 \\
\hline Grand mean & 26.87 & 41.25 & 34.06 & 46.74 & 36.17 & 41.46 & 0.61 & 1.22 & 0.92 \\
\hline L.S.D. 0.05 & & & & & & & & & \\
\hline Genotypes (G) & 5.34 & 3.54 & 3.15 & 7.5 & 3.11 & 3.43 & 0.2 & 0.19 & 0.13 \\
\hline Irrigation (I) & & & 0.97 & & & 1.06 & & & 0.04 \\
\hline G x I & & & 4.46 & & & 4.85 & & & 0.19 \\
\hline
\end{tabular}

\section{Physiological Traits}

Data in Table 3 show that significant reduction was observed in leaf relative water content \% (RWC) for all the genotypes under drought stress similar results were observed by Malik et al. (1999); Rahman et al. (2000); Siddique et al. (2000) and Parida et al. (2007). Significant differences among cotton genotypes under both treatments were observed.

The highest $\mathrm{RWC} \%$ was maintained by $\mathrm{P} 1 \times \mathrm{P} 5, \mathrm{P} 3 \times \mathrm{P} 4$ followed by Giza 86 (P2) under normal irrigation and P3xP4 followed by $\mathrm{P} 1 \mathrm{xP} 5$ then $\mathrm{P} 1 \mathrm{xP} 4$ and $\mathrm{P} 5 \mathrm{xP} 6$ under drought stress. Combined analysis data reveal that the highest value of $\mathrm{RWC} \%$ obtained by $\mathrm{P} 1 \mathrm{xP} 5$ and $\mathrm{P} 3 \mathrm{xP} 4$ genotypes under both normal and stress treatments. Oxidative injury at the cellular level under water stress has high lipid peroxidation which decreased stability of cell membrane and led to lose more water from cells (Sairam and Saxena, 2000; Sanchez-Blanco et al., 2006 and Abdalla and Khoshiban, 2007)

Electrolyte leakage (EL \%) is routinely used as indicator to assess the integrity and permeability of cell membrane and resulting in leakage of intracellular contents (Arvin and Donnelly, 2008). EL \% was relatively changed in the genotype leaves under normal and stress treatments as shown in Table 3. Results show that the normal water treatment caused significant decrease in EL \% of the genotypes leaves in comparison with drought stress. P2xP3, Giza 86 followed by $\mathrm{P} 4 \mathrm{xP} 6$ and $\mathrm{P} 3 \mathrm{xP} 4$ recorded the lowest values of $\mathrm{EL} \%$ under normal water condition. P3xP4 followed by P1xP5, P1xP4, Giza 86 and P5xP6 recorded the lowest values of EL \% under drought stress. Combined analysis results elucidate that the genotypes P1xP5 and $\mathrm{P} 3 \mathrm{xP} 4$ could survive better under non-stressed and stressed conditions. Similar trends were obtained by Premachandra et al., (1991); Sairam and Saxena (2000); Bajji et al., (2002); Sibet and Birol, (2007). The plasma membrane is generally protected from desiccation-induced damage by presence of membrane-compatible solutes, such as sugars and amino acid. Therefore, a link may exist between the capacity for osmotic adjustment and degree of membrane protection (Sibet and Birol, 2007). The water stress-induced decrease in membrane stability indicates the extent of lipid peroxidation caused by active oxygen species (Menconi et al., 1995 and Sibet and Birol, 2007).

Membrane stability index (MSI \%) has been measured as percentage injury of leaf tissues of cotton genotypes under drought stress, it can be used to screen for drought stress. Considerable genotypic variation for cell membrane stability index was present among the cotton genotypes Table 3. The highest values of MSI\% were recorded by the genotypes P5xP6 followed by Giza 86, P3xP4 and Giza 90 under the normal irrigation and $\mathrm{P} 3 \times \mathrm{P} 4, \mathrm{P} 1 \times \mathrm{P} 5, \mathrm{P} 5 \times \mathrm{P} 6$ and Tamcot C.E. under drought stress. The combined analysis data indicate that higher MSI\% was recorded by the genotypes $\mathrm{P} 5 \mathrm{xP} 6, \mathrm{P} 3 \mathrm{xP} 4$ under both treatments. These results were similar to those obtained by (Premachandra et al., 1991; Tripathy et al., 2000; Bajji et al., 2002 and Ashraf, 2009). The plasma membrane is generally protected from desiccation-induced damage by presence of membrane-

\section{Volume 4 Issue 11, November 2015}




\section{International Journal of Science and Research (IJSR) \\ ISSN (Online): 2319-7064 \\ Index Copernicus Value (2013): 6:14 | Impact Facter (2014)) 5:611}

compatible solutes, such as sugars and amino acid. Therefore, a link may exist between the capacity for osmotic adjustment and degree of membrane protection (Sibet and Birol, 2007). The drought stress induces decreasing in membrane stability which indicates that the extent of lipid peroxidation caused by active oxygen species (Dhindsa et al., 1981; Menconi et al., 1995 and Sibet and Birol, 2007).

Concerning chlorophyll 'a', 'b', total chlorophyll, chlorophyll $\mathrm{a} / \mathrm{b}$ ratio and chlorophyll stability index (CSI \%), it's found significant differences for chlorophyll 'a', 'b', total chlorophyll, chlorophyll $\mathrm{a} / \mathrm{b}$ ratio and CSI \% among the cotton genotypes under normal and drought conditions as shown in Table 3. Results in the present study indicate that the highest values were recorded by Giza 86 followed by P3xP4 and P5xP6 for chlorophyll 'a' ; P3xP4 followed by P5xP6 and Giza 80 for chlorophyll 'b'; P3xP4 followed by P5xP6 and Giza 80 for total chlorophyll and P2xP4 followed by $\mathrm{P} 2 \mathrm{xP} 6, \mathrm{P} 1 \mathrm{xP} 6$ and $\mathrm{P} 1 \times \mathrm{P} 2$ for chlorophyll $\mathrm{a} / \mathrm{b}$ under normal irrigation. Exposing plants to drought stress exerted minimum chlorophyll content of leaves in comparison with normal treatments. Highest values were recorded by P5xP6 followed by Tamcot C.E. and $\mathrm{P} 3 \mathrm{xP} 4$ for chlorophyll ' $\mathrm{a}$ ' ; $\mathrm{P} 3 \mathrm{xP} 4$ followed by $\mathrm{P} 1 \mathrm{xP} 3$ for chlorophyll 'b'; P5xP6 followed by $\mathrm{P} 3 \times \mathrm{P} 4$ and Tamcot C.E. for total chlorophyll and Giza 90xAustralian, Giza 86 and Deltapine for chlorophyll a/b ratio. Highest CSI \% was recorded by P3xP5, P1xP3, Tamcot C.E. and P5xP6. Combined analysis results elucidated that $\mathrm{P} 3 \times \mathrm{P} 4$ and $\mathrm{P} 5 \mathrm{xP} 6$ had highest values under normal and drought treatments in compared to the others Table 3. Similar trends were obtained by (Ashraf et al., 1994; Havaux, 1998; Anjum et al., 2003; Kiani et al., 2008; Massacci et al., 2008 and Patil et al., 2011). The decrement of chlorophyll content during drought stress could be related to photo-oxidation resulting from oxidative stress which reduces photosynthetic process (Delfine et al., 1998; Ashraf, 2009 and Hamayun et al., 2010).

\section{Seed cotton yield}

Regarding seed cotton yield per plant, data presented in Table 3 reveal that decreasing water irrigation level significantly decreased cotton yield per plant and reached its maximum values under normal irrigation. Similar results were obtained by DeTar (2008); Basal et al. (2009); Onder, et al. (2009); Aboeldhab et al. (2012) and Hamoda (2012). Results indicate that significant differences among genotypes under normal irrigation and highest seed cotton yield per plant was recorded by the genotypes $\mathrm{P} 3 \mathrm{xP} 4$ $\mathrm{P} 5 \mathrm{xP} 6$ followed by P1xP5. Under the drought stress, P3xP4, P5xP6 followed by Giza 90 and P1xP5 recorded the highest performance for seed cotton yield/plant. Combined analysis data indicate that the highest seed cotton per plant was recorded by genotypes $\mathrm{P} 3 \times \mathrm{P} 4, \mathrm{P} 5 \mathrm{xP} 6$ and $\mathrm{P} 1 \times \mathrm{P} 5$. Water stress during peak flowering had the most detrimental effects on seed cotton yield (Orgaz et al., 1992 and Krieg, 1997).

\begin{tabular}{|c|c|c|c|c|c|c|c|c|c|c|c|c|}
\hline \multirow[b]{2}{*}{ Genotypes } & \multicolumn{3}{|c|}{ Relative water content $\%$} & \multicolumn{3}{|c|}{ Electrolyte leakage \% } & \multicolumn{3}{|c|}{ Membrane stability index } & \multicolumn{3}{|c|}{ Chlorophyll a ( mg g F W.) } \\
\hline & $\mathrm{N}$ & $\mathrm{D}$ & Combined & $\mathrm{N}$ & $\mathrm{D}$ & Combined & $\mathrm{N}$ & $\mathrm{D}$ & Combined & $\mathrm{N}$ & $\mathrm{D}$ & Combined \\
\hline Giza $80(\mathrm{P} 1)$ & 61.05 & 37.41 & \begin{tabular}{|l|}
49.23 \\
\end{tabular} & 13.72 & 46.79 & 30.25 & 57.07 & 17.88 & 37.48 & 0.82 & 0.54 & 0.68 \\
\hline Giza $86(\mathrm{P} 2)$ & 89.18 & 27.59 & 58.38 & 9.14 & 71.59 & 40.36 & 61.31 & 12.22 & 36.76 & 0.94 & 0.42 & 0.68 \\
\hline Giza $90(\mathrm{P} 3)$ & 77.08 & 36.37 & 56.72 & 9.17 & 57.18 & 33.18 & 60.08 & 19.94 & 40.01 & 0.86 & 0.51 & 0.69 \\
\hline Giza 90 x Australian (P4) & 71.25 & 38.81 & 55.03 & 20.5 & 51.2 & 35.85 & 48.37 & 14.98 & 31.68 & 0.86 & 0.46 & 0.66 \\
\hline Tamcot C. E. (P5) & 58.25 & 31.79 & 45.02 & 14.54 & 60.43 & 37.48 & 45.75 & 23.76 & 34.76 & 0.86 & 0.68 & 0.77 \\
\hline Deltapine (P6) & 57.68 & 29.83 & 43.76 & 20.64 & 63.06 & 41.85 & 36.63 & 11.75 & 24.19 & 0.81 & 0.38 & 0.6 \\
\hline Mean & 69.08 & 33.63 & 51.36 & 14.62 & 58.38 & 36.5 & 51.54 & 16.76 & 34.15 & 0.86 & 0.5 & 0.68 \\
\hline $\mathrm{P} 1 \mathrm{xP} 2$ & 62.21 & 34.37 & 48.29 & 17.56 & 73.74 & 45.65 & 44.06 & 16.22 & 30.14 & 0.89 & 0.35 & 0.62 \\
\hline $\mathrm{P} 1 \times \mathrm{P} 3$ & 71.11 & 39.72 & 55.42 & 17.33 & 53.26 & 35.29 & 51.4 & 21.94 & 36.67 & 0.78 & 0.49 & 0.64 \\
\hline $\mathrm{P} 1 \times \mathrm{P} 4$ & 53.53 & 40.78 & 47.15 & 18.15 & 46.59 & 32.37 & 55.05 & 22.4 & 38.72 & 0.82 & 0.44 & 0.63 \\
\hline $\mathrm{P} 1 \mathrm{xP5}$ & 92.95 & 43.65 & 68.3 & 13.72 & 43.08 & 28.4 & 59.37 & 24.33 & 41.85 & 0.88 & 0.52 & 0.7 \\
\hline $\mathrm{P} 1 \times \mathrm{P} 6$ & 76.47 & 33.21 & 54.84 & 13.76 & 72.84 & 43.3 & 49.47 & 18.5 & 33.99 & 0.75 & 0.3 & 0.53 \\
\hline $\mathrm{P} 2 \mathrm{xP} 3$ & 68.84 & 34.57 & 51.71 & 8.91 & \begin{tabular}{|l|}
77.49 \\
\end{tabular} & 43.2 & 44.55 & 18 & 31.27 & 0.82 & 0.28 & 0.55 \\
\hline $\mathrm{P} 2 \mathrm{xP} 4$ & 71.54 & 29.74 & 50.64 & 16.36 & \begin{tabular}{|l|}
73.93 \\
\end{tabular} & 45.15 & 37.02 & 17.09 & 27.06 & 0.78 & 0.28 & 0.53 \\
\hline $\mathrm{P} 2 \mathrm{xP5}$ & 50.7 & 31.94 & 41.32 & 38.72 & \begin{tabular}{|l|}
66.49 \\
\end{tabular} & 52.6 & 48.59 & 19.93 & 34.26 & 0.89 & 0.35 & 0.62 \\
\hline $\mathrm{P} 2 \mathrm{xP} 6$ & 51.8 & 28.41 & 40.1 & 30.62 & 71.52 & 51.07 & 51.9 & 12.11 & 32.01 & 0.76 & 0.23 & 0.5 \\
\hline $\mathrm{P} 3 \mathrm{xP} 4$ & 92.72 & 44.1 & 68.41 & 11.64 & 36.55 & 24.1 & 61.02 & 25.77 & 43.39 & 0.93 & 0.59 & 0.76 \\
\hline $\mathrm{P} 3 \mathrm{xP5}$ & 68.33 & 39.6 & 53.97 & 19.44 & \begin{tabular}{|l|}
48.89 \\
\end{tabular} & 34.17 & 45.21 & 19.01 & 32.11 & 0.72 & 0.51 & 0.62 \\
\hline P3xP6 & 63.55 & 33.8 & 48.67 & 24.31 & 66.08 & 45.2 & 56.57 & 16.38 & 36.47 & 0.87 & 0.36 & 0.62 \\
\hline $\mathrm{P} 4 \mathrm{xP5}$ & 60.89 & 36.16 & 48.52 & 22.96 & 70.78 & 46.87 & 47.48 & 12.72 & 30.1 & 0.81 & 0.29 & 0.55 \\
\hline $\mathrm{P} 4 \mathrm{xP} 6$ & 65.43 & 33.53 & 49.48 & 11.11 & \begin{tabular}{|l|}
55.62 \\
\end{tabular} & 33.36 & 55.24 & 18.91 & 37.07 & 0.8 & 0.31 & 0.56 \\
\hline $\mathrm{P} 5 \mathrm{xP} 6$ & 67.3 & 40.62 & 53.96 & 14.61 & \begin{tabular}{|l|}
47.5 \\
\end{tabular} & 31.06 & 65.25 & 23.92 & 44.58 & 0.91 & 0.69 & 0.8 \\
\hline Mean & 67.82 & 36.28 & 52.05 & 18.61 & \begin{tabular}{|l|}
60.29 \\
\end{tabular} & 39.45 & 51.48 & 19.15 & 35.31 & 0.83 & 0.4 & 0.62 \\
\hline Grand mean & 68.18 & 35.52 & 51.85 & 17.47 & 66.46 & 41.96 & 51.49 & 18.46 & 34.98 & 0.84 & 0.43 & 0.63 \\
\hline L.S.D. 0.05 & & & & & & & & & & & & \\
\hline Genotypes (G) & 1.38 & 1.09 & 0.87 & 1.59 & 2.09 & 1.29 & 0.81 & 1.48 & 0.83 & 0.05 & 0.03 & 0.03 \\
\hline Irrigation (I) & & & 0.27 & & & 0.4 & & & 0.26 & & & 0.01 \\
\hline $\mathrm{G} \times \mathrm{I}$ & & & 1.23 & & & 1.83 & & & 1.18 & & & 0.04 \\
\hline
\end{tabular}


International Journal of Science and Research (IJSR)

ISSN (Online): 2319-7064

Index Copernicus Value (2013): 6:14 | Impact Factor (2014): 5:611

\begin{tabular}{|c|c|c|c|c|c|c|c|c|c|c|c|c|c|}
\hline \multirow{2}{*}{ Genotypes } & \multicolumn{3}{|c|}{$\begin{array}{l}\text { Chlorophyll b ( mg g F } \\
\text { W.) }\end{array}$} & \multicolumn{3}{|c|}{$\begin{array}{l}\text { Total Chlorophyll } \\
\text { (mg g F W.) }\end{array}$} & \multicolumn{3}{|c|}{ Chlorophyll a/b ratio } & \multirow{2}{*}{ 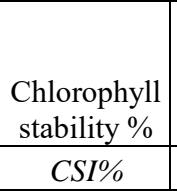 } & \multicolumn{3}{|c|}{ Seed cotton yield/ plant $(\mathrm{g})$} \\
\hline & $\mathrm{N}$ & $\mathrm{D}$ & Combined & $\mathrm{N}$ & D & Combined & $\mathrm{N}$ & $\mathrm{D}$ & Combined & & $\mathrm{N}$ & $\mathrm{D}$ & Combined \\
\hline Giza 80 (P1) & 0.53 & 0.2 & \begin{tabular}{|l|}
0.37 \\
\end{tabular} & 1.36 & 0.75 & \begin{tabular}{|l|}
1.06 \\
\end{tabular} & 1.55 & 2.65 & \begin{tabular}{|l|}
2.1 \\
\end{tabular} & 55.42 & 50.02 & 29.63 & 39.82 \\
\hline Giza $86(\mathrm{P} 2)$ & 0.52 & 0.13 & 0.33 & 1.47 & 0.56 & 1.02 & 1.79 & 3.2 & 2.5 & 39.65 & 62.66 & 18.97 & 40.82 \\
\hline Giza $90(\mathrm{P} 3)$ & 0.47 & 0.21 & 0.34 & 1.34 & 0.73 & 1.04 & 1.83 & 2.41 & 2.12 & 58.01 & 55.44 & 33.14 & 44.29 \\
\hline $\begin{array}{c}\text { Giza } 90 \mathrm{x} \\
\text { Australian } \\
(\mathrm{P} 4)\end{array}$ & 0.5 & 0.14 & 0.32 & 1.36 & 0.59 & 0.98 & 1.73 & 3.37 & 2.55 & 42.52 & 49.65 & 22.32 & 35.99 \\
\hline $\begin{array}{c}\text { Tamcot C. E. } \\
(\mathrm{P} 5)\end{array}$ & 0.51 & 0.22 & 0.37 & 1.36 & 0.9 & 1.13 & 1.69 & 3.13 & 2.41 & 62.01 & 63.51 & 29.61 & 46.56 \\
\hline Deltapine (P6) & 0.44 & 0.12 & 0.28 & 1.26 & 0.51 & 0.88 & 1.83 & 3.16 & 2.5 & 40.17 & 60.58 & 20.93 & 40.75 \\
\hline Mean & 0.5 & 0.17 & 0.34 & 1.36 & 0.67 & 1.02 & 1.74 & 2.99 & 2.36 & 49.63 & 56.98 & 25.77 & 41.37 \\
\hline P1xP2 & 0.44 & 0.16 & 0.3 & 1.33 & 0.51 & 0.92 & 2 & 2.22 & 2.11 & 39.01 & 61.83 & 18.02 & 39.92 \\
\hline $\mathrm{P} 1 \times \mathrm{P} 3$ & 0.45 & 0.29 & 0.37 & 1.23 & 0.78 & 1.01 & 1.76 & 1.68 & 1.72 & 64.76 & 62.89 & 27.46 & 45.17 \\
\hline $\mathrm{P} 1 \times \mathrm{P} 4$ & 0.47 & 0.3 & 0.38 & 1.3 & 0.74 & 1.02 & 1.75 & 1.5 & 1.62 & 56.32 & 47.73 & 24.97 & 36.35 \\
\hline P1xP5 & 0.47 & 0.27 & 0.37 & 1.35 & 0.79 & 1.07 & 1.88 & 1.9 & 1.89 & 59.85 & 71.18 & 32.49 & 51.84 \\
\hline $\mathrm{P} 1 \times \mathrm{P} 6$ & 0.34 & 0.17 & 0.25 & 1.09 & 0.47 & 0.78 & 2.19 & 2.04 & 2.12 & 45.48 & 54.24 & 21.35 & 37.8 \\
\hline $\mathrm{P} 2 \mathrm{xP} 3$ & 0.45 & 0.11 & 0.28 & 1.27 & 0.39 & 0.83 & 1.84 & 2.6 & 2.22 & 30.41 & 45.07 & 15.69 & 30.38 \\
\hline $\mathrm{P} 2 \times \mathrm{x} 4$ & 0.34 & 0.18 & 0.26 & 1.12 & 0.46 & 0.79 & 2.3 & 1.57 & 1.94 & 40.95 & 42.21 & 15.85 & 29.03 \\
\hline $\mathrm{P} 2 \times \mathrm{xP} 5$ & 0.47 & 0.24 & 0.36 & 1.35 & 0.6 & 0.98 & 1.9 & 1.45 & 1.68 & 43.54 & 60.35 & 24.91 & 42.63 \\
\hline $\mathrm{P} 2 \times \mathrm{P} 6$ & 0.35 & 0.19 & 0.27 & 1.11 & 0.42 & 0.77 & 2.2 & 1.26 & 1.73 & 37.93 & 48.25 & 19.05 & 33.65 \\
\hline $\mathrm{P} 3 \mathrm{xP} 4$ & 0.66 & 0.32 & 0.49 & 1.59 & 0.91 & 1.25 & 1.42 & 1.8 & 1.61 & 58.41 & 85.72 & 38.52 & 62.12 \\
\hline P3xP5 & 0.38 & 0.2 & 0.29 & 1.1 & 0.71 & 0.91 & 1.89 & 2.5 & 2.2 & 64.27 & 51.82 & 23.03 & 37.42 \\
\hline P3xP6 & 0.46 & 0.12 & 0.29 & 1.34 & 0.48 & 0.91 & 1.88 & 3.01 & 2.45 & 39.13 & 60.87 & 23.78 & 42.32 \\
\hline $\mathrm{P} 4 \times \mathrm{P} 5$ & 0.4 & 0.15 & 0.28 & 1.22 & 0.44 & 0.83 & 2.03 & 1.97 & 2 & 34.74 & 51.45 & 19.75 & 35.6 \\
\hline $\mathrm{P} 4 \mathrm{xP} 6$ & 0.49 & 0.2 & 0.35 & 1.3 & 0.51 & 0.91 & 1.64 & 1.5 & 1.57 & 38.97 & 62.1 & 25.82 & 43.96 \\
\hline $\mathrm{P} 5 \times \mathrm{P} 6$ & 0.63 & 0.26 & 0.45 & 1.54 & 0.95 & 1.25 & 1.46 & 2.62 & 2.04 & 59.73 & 80.48 & 37.26 & 58.87 \\
\hline Mean & 0.45 & 0.21 & 0.33 & 1.28 & 0.61 & 0.95 & 1.88 & 1.97 & 1.93 & 47.57 & 59.08 & 24.53 & $\begin{array}{l}41.8 \\
\end{array}$ \\
\hline Grand mean & 0.47 & 0.2 & 0.33 & 1.3 & 0.63 & 0.97 & 1.84 & 2.26 & 2.05 & 48.16 & 58.03 & 25.15 & 41.59 \\
\hline L.S.D. 0.05 & & & & & & & & & & & & & \\
\hline $\begin{array}{l}\text { Genotypes } \\
(\mathrm{G})\end{array}$ & 0.04 & 0.03 & 0.03 & 0.07 & 0.04 & 0.04 & 0.22 & 0.36 & 0.21 & 3.89 & 7.31 & 3.45 & 3.98 \\
\hline Irrigation (I) & & & 0.01 & & & 0.01 & & & 0.06 & & & & 1.23 \\
\hline G x I & & & 0.04 & & & 0.05 & & & 0.29 & & & & 5.63 \\
\hline
\end{tabular}

Correlation study between yield and morphological traits Under normal and drought treatments Table 4, seed cotton yield per plant was positively and significantly correlated with root length $(\mathrm{cm})$. It is notable that shoot length $(\mathrm{cm})$ is negatively and significantly correlated with yield under drought and not under normal. Therefore, it could be concluded that shoot length $(\mathrm{cm})$ could be used as selection criterion for high yield under drought stress. Similar trend were reported by Afiah and Ghoneim (2000) and Iqbal et al., (2003).

Table 4: Correlation between yield and morphological traits under normal (upper diagonal) and drought (lower diagonal) treatments

\begin{tabular}{|c|c|c|c|c|}
\hline Traits & Root/Shoot ratio & Shoot length $(\mathrm{cm})$ & Root length $(\mathrm{cm})$ & Seed cotton yield/ plant \\
\hline Root/Shoot ratio & 1 & $-0.702^{* *}$ & $0.810^{* *}$ & 0.343 \\
\hline Shoot length $(\mathrm{cm})$ & $-0.558^{* *}$ & 1 & -0.185 & 0.031 \\
\hline Root length $(\mathrm{cm})$ & $0.156^{* *}$ & $0.721^{* *}$ & 1 & $0.585^{* *}$ \\
\hline Seed cotton yield/ plant & 0.04 & $0.611^{* *}$ & $0.715^{* *}$ & 1 \\
\hline * and** denote significant at 0.05 and 0.01 levels of probability, respectively. \\
\hline
\end{tabular}

\section{Correlation Study between Yield and Physiological Traits}

To identify the most desirable physiological traits as screening criteria, correlation between yield and physiological traits is presented in Table 5. Under normal irrigation, correlation analyses reveal that yield was positively and significantly correlated with total chlorophyll, chlorophyll 'b', chlorophyll 'a', membrane stability index and relative water content $\%$ but negatively and significantly correlated with chlorophyll $\mathrm{a} / \mathrm{b}$ ratio and electrolyte leakage $\%$. Under drought treatment, it's found that yield was positively and significantly correlated with total chlorophyll, chlorophyll ' $b$ ', chlorophyll ' $a$ ', membrane stability index and relative water content $\%$ and negatively and significantly correlated with electrolyte leakage \%. 


\section{International Journal of Science and Research (IJSR) ISSN (Online): 2319-7064 \\ Index Copernicus Value (2013)! 6:14 | Impact Facter (2014)! 5:611}

Maximum correlation values were recorded by total chlorophyll, chlorophyll ' $b$ ', chlorophyll 'a', and membrane

stability index under normal and drought treatments.

Table 27: Correlation between yield and physiological traits under normal (upper diagonal) and drought

\begin{tabular}{|c|c|c|c|c|c|c|c|c|}
\hline & \multicolumn{3}{|c|}{ (lower diagonal) treatments } & \multirow{2}{*}{ Chl. a } & \multirow[b]{2}{*}{ MSI } & \multirow{2}{*}{ EL \% } & \multirow{2}{*}{ RWC \% } & \multirow[b]{2}{*}{ SCY } \\
\hline Traits & Chl. a/b & Total Chl. & Chl. b & & & & & \\
\hline Chl. a/b & 1 & $-0.820 * *$ & $-0.935 * *$ & $-0.550 * *$ & $-0.447 *$ & 0.31 & -0.123 & $-0.566^{* *}$ \\
\hline Total Chl. & 0.25 & 1 & $0.960 * *$ & $0.922 * *$ & $0.602 * *$ & -0.301 & 0.32 & $0.714 * *$ \\
\hline Chl. b & -0.419 & $0.762 * *$ & 1 & $0.779 * *$ & $0.560 * *$ & -0.319 & 0.261 & $0.698 * *$ \\
\hline Chl. a & $0.506^{*}$ & $0.958 * *$ & $0.546^{*}$ & 1 & $0.554 * *$ & -0.217 & 0.346 & $0.639 * *$ \\
\hline MSI & -0.106 & $0.796^{* *}$ & $0.811 * *$ & $0.675 * *$ & 1 & -0.289 & 0.427 & $0.552 * *$ \\
\hline EL \% & -0.076 & $-0.826 * *$ & $-0.747 * *$ & $-0.743 * *$ & $-0.656 * *$ & 1 & $-0.637 * *$ & -0.183 \\
\hline RWC & -0.011 & $0.680 * *$ & $0.668 * *$ & $0.593 * *$ & $0.691 * *$ & $-0.819 * *$ & 1 & $0.446^{*}$ \\
\hline SCY & 0.096 & $0.897 * *$ & $0.758 * *$ & $0.826^{* *}$ & $0.767 * *$ & $-0.816^{* *}$ & $0.663 * *$ & 1 \\
\hline \multicolumn{9}{|c|}{$*$ and $* *$ denote significant at 0.05 and 0.01 levels of probability, respectively. } \\
\hline \multicolumn{9}{|c|}{ SCY, RWC, EL, MSI, Chl. a, Chl. B, total Chl., Chl. a/b are seed cotton yield/ plant, relative water content\%, } \\
\hline \multicolumn{9}{|c|}{ electrolyte leakage $\%$, membrane stability index, chlorophyll a, b, total chlorophyll ( mg g F W.), chlorophyll } \\
\hline
\end{tabular}

\section{Conclusion}

By reviewing the above results, it's concluded that most morphological and physiological traits are more effective criteria in identifying high yield genotypes under drought and it is better to use each of chlorophyll ' $a$ ', electrolyte leakage $\%$, membrane stability index and relative water content $\%$ as efficient screening method able to screen large amounts of plant material in the shortest time possible and select the most efficient genotypes.

\section{References}

[1] Abdalla, M. M. and N. H. El-Khoshiban, (2007). The influence of water stress on growth, relative water content, photosynthetic pigments, some metabolic and hormonal contents of two Triticum aestivum cultivars. J. of Appl. Sci. Res. 3(12): 2062-2074.

[2] Aboeldhab, A. A., M. A. Amany and S. A. F. Hamoda, (2012). Response of some Egyptian cotton cultivars to different drip irrigation durations under sandy soil conditions in Wadi El-natron. J. Plant Production, Mansoura Univ., 3 (2), 369-384.

[3] Afiah, S. A. N. and E. M. Ghoneim (2000). Correlation, stepwise and path coefficient analysis in Egyptian cotton under saline conditions. Arab Univ. J. Agric. Sci., (8): 607-618.

[4] Afshari R. T.; R. Angoshtaril and S. Kalantari (2011). Effects of light and different plant growth regulators on induction of callus growth in rapeseed (Brassica napus L.) genotypes. Plant, Omics. J., 4(2): 60-67.

[5] Allen, R. G., W. O. Pruitt, J. A. Businger, L. J. Fritschen, M. E. Jensen and F. H. Quinn, (1996). Evaporation and Transpiration $m$ ASCE Handbook of Hydrology. New York, NY. USA., pp.125-252.

[6] Anjum, F.; M. Yaseen; E. Rasul; A. Wahid and S. Anjum (2003). Water stress in barley (Hordeum vulgare L.). I. Effect on chemical composition and chlorophyll contents. Pakistan J. Agric. Sci., (40): 4549.

[7] Apel, K. and H. Hirt, (2004). Reactive oxygen species: metabolism, oxidative stress and signal transduction, Annu. Rev. Plant Biol., 55, 373-399.
[8] Araus, J. L.; T. Amaro; J. Voltas; H. Nakkoul and M. M. Nachit (1998). Chlorophyll fluorescence as a selection criterion for grain yield in durum wheat under Mediterranean conditions. Field Crops Research, (55): 209-223.

[9] Arora, R.; M. E. Wisniewski and R. Scorza (1992). Cold acclimation in genetically related (sibling) deciduous and evergreen peach (Prunus persica L. Batsch). I Seasonal changes in cold hardiness and polypeptides of bark and xylem tissues. Plant Physiol., (99): 1562-1568.

[10]Arvin, M .J. and D. J. Donnelly (2008). Screening potato cultivars and wild species to abiotic stresses using an electrolyte leakage bioassay. J. Agric. Sci.Technol., (10): 33-42.

[11] Ashraf, M. (2009). Biotechnological approach of improving plant salt tolerance using antioxidants as markers. Biotechnol Adv., (27): 84-93.

[12] Ashraf, M. and S. Ahmad (2000). Influence of sodium chloride on ion accumulation, yield components and fibre characteristics in salt tolerant and salt-sensitive lines of cotton (Gossypium hirsutum L.). Field Crop Res., (66):115-127.

[13] Ashraf, M. Y.; A. R. Azmi; A. H. Khan and S. S. M. Naqvi (1994). Water relations in different wheat (Triticum aestivum L.) genotypes under soil water deficits. Acta Physiol. Plant., (16): 231-240.

[14] Aujla, M. S., H. S. Thind and G. S. Buttar, (2005). Cotton yield and water use efficiency at various levels of water and $\mathrm{N}$ through drip irrigation under two methods of planting. Agr. Water Mgt. 71,167-179.

[15] Bajji, M.; J. Kinet and S. Lutts (2002). The use of the electrolyte leakage method for assessing cell membrane stability as a water stress tolerance test in durum wheat, Plant Growth Regul., (36): 61-70.

[16] Basal, H., N. Dagdelen, A. Unay and E. Yilmaz, (2009). Effects of deficit drip irrigation ratios on cotton (Gossypium hirsutum L.) yield and fibre quality. J Agron Crop Sci., 195, 19-29.

[17] Basal, H.; P. Bebeli,;C. W. Smith and P. Thaxton (2003). Root growth parameters of converted races of upland cotton (Gossypium hirsutum L.) and two BC2F2 populations. Crop Sci., (43): 1983-1988. 


\section{International Journal of Science and Research (IJSR) \\ ISSN (Online): 2319-7064 \\ Index Copernicus Value (2013): 6:14 | Impact Facter (2014): 5:611}

[18] Chaitante, D.; D. A. Iorio; L. Maiuro and S. G. Scippa (2000). Effect of water stress on root meristems in woody and herbaceous plants during the first stage of development, Function and Physiology: 245-258.

[19] Clarke, J.M.; and T.M. McCaig (1982). Evaluation of techniques for screening for drought resistance in wheat. Crop. Sci., (22): 1036-1040.

[20] Collado, M. B.; M. J. Arturi; M. B. Aulicino and M. C. Molina (2010). Identification of salt tolerance in seedling of maize (Zea mays L.) with the cell membrane stability trait. International Research J. Plant Sci., 1(5): 126-132.

[21] Cook, C. G. and K. M. El-Zik (1992). Cotton seedling and first-bloom plant characteristics: Relationships with drought-influenced boll abscission and lint yield. Crop Sci. (32): 1464-1467.

[22] Dağdelen N., E. Yılmaz, F. Sezgin, and T. Gürbüz, (2006). Water-yield relation and water use efficiency of cotton (Gossypium hirsutum L.) and second crop corn (Zea mays L.) in western Turkey. Agric Water Manag $82,63-85$

[23] De Ronde, J. A.; A. Van Der Mescht and H. S. F Steyn (2000). Proline accumulation in response to drought and heat stress in cotton. Afr. Crop Sci. J., (8): 85-92

[24] Delfine, S.; A. Alvino; M. Zacchini and F. Loreto (1998). Consequences of salt stress on diffusive conductance, Rubisco characteristics and anatomy of spinach leaves. Aust J. Plant Physiol., (25): 395-402.

[25] DeTar, W. R. (2008). Yield and growth characteristics for cotton under various irrigation regimes on sandy soil. Agric. Water Manag, (95): 69-76.

[26] Dhanda, S. S.; G. S. Sethi and R.K. Behl (2004). Indices of drought tolerance in wheat genotypes at early stages of plant growth, J. Agron. Crop Sci., (190): 6-12.

[27] Dhindsa, R. S. and W. Matowe (1981). Drought tolerance in two mosses correlated with enzymatic defense against lipid peroxidation. J. Exp. Bot., (32): 79-91

[28] Gomez K. A and A. A. Gomez, (1984). Statistical procedures for agricultural research. John Wiley and sons, Inc. London, UK ( $2^{\text {nd }}$ ed. $)$, pp. 13-175.

[29] Hamayun, M.; S. A. Khan; Z. K. Shinwari; A. L. Khan; N. Ahmad and I. J. Lee (2010). Effect of polyethylene glycol induced drought stress on physiohormonal attributes of soybean. Pakistan J. Bot., (42): 977-986.

[30] Hamoda, S. A. F., (2012). Response of Giza 90 cotton cultivar to foliar application of some drought tolerance inducers under water stress and high temperature conditions in upper Egypt. J. Plant Prod., Mansoura Univ., 3(3), 493-507.

[31] Havaux, M. (1998). Carotenoids as membrane stabilizers in chloroplasts. Trends Plant Sci., (3): 147151.

[32] Hiscox, J. D., and G.F. Israelstam (1979). A method for the extraction of chlorophyll from leaf tissue without maceration". Canadian Journal of Botany, (57): 13321334.

[33] Howard, D, D.; C. O. Gwathney; G. M. Lessman and R. K. Roberts (2001). Fertilizer additive rate and plant growth regulator effects on cotton. J. Cotton Sci., (5): 42-52.
[34] Hufstetler, V. E.; R. Boerma; T. E. J. Carter and H. J. Earl (2007). Genotypic variation for three physiological traits affecting drought tolerance in soybean. Crop Sci. (47): 25-35.

[35] Hurd, E. A. and E. D. Spratt (1975). Root pattern in crops related to water and nutrition uptake. Physiological aspects of dry land farming (Gupta US., Ed.). Oxford \& IBH Publ. Co., New Delhi.

[36] Iqbal, M.; M. A. Chang; M. Z. Iqbal; M .U. Hassan; A. Nasir and N. U. Islam (2003). Correlation and path coefficient analysis of earliness and agronomic characters of upland cotton in Multan. Pak. J. Agron., (2): 160-168.

[37] Johnson, D. A. (1980). Improvement of perennial herbaceous plants for drought-stressed western rangelands. p. 419-433. In N.C. Turner and P.J. Kramer (ed.) Adaptation of plants to water and high temperature stress. John Wiley \& Sons, New York.

[38] Kamara, AY; A. Menkir; B. Babu-Apraku and O. Ibikunle (2003). The influence of drought stress on growth, yield and yield components of stressed maize genotypes. J. Agric. Sci. (141): 43-50.

[39] Kiani, S.P.; P. Maury; A. Sarrafi and P. Grieu (2008). QTL analysis of chlorophyll fluorescence parameters in sunflower (Helianthus annuus L.) under well-watered and water-stressed conditions. Plant Sci., (175): 565-573.

[40] Krieg, D. R., (1997). Genetic and environmental factors affecting productivity of cotton. In: Dugger, P., Richter, D.A. (Eds.), Proceeding Beltwide Cotton Conf., New Orleans, LA, January 7-10 Natl. Cotton Counc. Am., Memphis, TN, $1347 \mathrm{p}$.

[41] Kumar, N.; A. S. Nandwal; S. Devi; K. D. Sharma; A. Yadav and R. S. Waldia (2010). Root characteristics, plant water status and $\mathrm{CO}_{2}$ exchange in relation to drought tolerance in chickpea (8). ejournal.icrisat.org. An Open Access Journal published by ICRISAT.

[42] Lambers, H.; F. S. Chapin and T. Pons (1998). Plant Physiological Ecology. Springer-Verlag., New York.

[43] Mahajan, S. and N. Tuteja (2005). Cold, salinity and drought stresses: An overview Archives of Biochemistry and Biophysics., (444): 139-158

[44] Makbul, S., N. Saruhan-guler, N. Durmus and S. Guven, (2011). Changes in anatomical and physiological parameters of soybean under drought stress. Turk. J. Bot., 35, 369-377.

[45] Malik, T.A.; D. Wright and D.H. Virk (1999). Inheritance of net photosynthesis and transpiration efficiency in spring wheat (Triticum aestivum L.) under drought. Plant Breed., (118): 93-95.

[46] Massacci, A.; S. M. Nabiev; L. Pietrosanti; S. K. Nematov; T. N. Chernikova; K. Thor and J. Leipner (2008). Response of the photosynthetic apparatus of cotton (Gossypium hirsutum) to the onset of drought stress under field conditions studied by gas-exchange analysis and chlorophyll fluorescence imaging. Plant Physiol. Biochem., (46): 189-195.

[47] Menconi, M; C. L. M. Sgherri; C. Pinzino and F. Navari-Izzo (1995). Activated oxygen production and detoxification in wheat plants subjected to a water deficit programme. J. Exp. Bot., (46): 1123-1130. 


\section{International Journal of Science and Research (IJSR) \\ ISSN (Online): 2319-7064 \\ Index Copernicus Value (2013): 6:14 | Impact Factor (2014)! 5:611}

[48] Moaveni, P., (2011). Effect of water deficit stress on some physiological traits of wheat (Triticum aestivum). Agric. Sci. Res. J., 1(1), 64-68.

[49] Mode, C. J. and H. F. Rhobinson, (1959). Pleotropism and genetic divergence and covariance. Biometrics 15, 518-537.

[50] Moinuddin, R. A; A. Fisher; K. D. Sayre and M. P. Reynolds (2005). Osmotic adjustment in wheat in relation to grain yield under water deficit environments. Agron. J., ( 97):1062-1071.

[51] Onder, D., Y. Akiscan, S. Onder, and M. Mert, (2009). Effect of different irrigation water level on cotton yield and yield components. African J. Biotech. 8, 1536-1544.

[52] Orgaz, F., L. Mateos and E. Fereres, (1992). Season length and cultivars determine the optimum evapotranspiration deficit in cotton. Agron. J. 84, 700706.

[53] Pace, P. F.; H. T. Cralle; S. H. M El-Halawany; J. T. Cothren and S. A. Senseman (1999). Drought-induced changes in shoot and root growth of young cotton plants. J. Cot. Sci. (3):183-187.

[54] Parida, A. K.; V. S. Dagaonkar; M. S. Phalak; G. V. Umalkar and L. P. Aurangabadkar (2007). Alterations in photosynthetic pigments, protein and osmotic components in cotton genotypes subjected to short-term drought stress followed by recovery Plant Biotechnol., Rep., (1): 37-48.

[55] Patil, M. D.; D. P. Biradar; V. C. Patil and B. S. Janagoudar (2011). Response of cotton genotypes to drought mitigation practices Am-Euras. J. Agric. \& Environ. Sci., 11 (3): 360-364.

[56] Pettigrew, W. T. (2004). Moisture deficit effects on cotton lint yield, yield components, and boll distribution. Agron. J., 96, 377-383.

[57] Premachandra G.S.; H. Saneoka; M. Kanaya and S. Ogata (1991). Cell membrane stability and leaf surface wax content as affected by increasing water deficits in maize, J. Exp. Bot., (42): 167-171.

[58] Prior, S. A.; G. B. Runion; R. J. Mitchell; H. H. Rogers and J. S. Amthor (1997). Effects of atmospheric $\mathrm{CO}_{2}$ on long leaf pine: productivity and allocation as influenced by nitrogen and water. Tree Physiology, (17): 397-405.

[59] Rahman, S.; M.S. Shaheen; M. Rahman and T.A. Malik (2000). Evaluation of excised leaf water loss and relative water content as screening techniques for breeding drought resistant wheat. Pak. J. Biol. Sci., (3): 663-665.

[60] Reddy, A.R., K.V. Chiatanya and M. Vivekanandan, (2004). Drought-induced responses of photosynthesis and antioxidant metabolism in higher plants. J. Plant Physiol., 161, 1189-1202.

[61] Riaz, M.; J. Farooq; G. Sakhawat; A. Mahmood; M.A. Sadiq and M. Yaseen (2013). Genotypic variability for root/shoot parameters under water stress in some advanced lines of cotton (Gossypium hirsutum L.). Genetics and Molecular Research 12 (1): 552-561.

[62] Rizza, F; F. W. Badeck; L. Cattivelli and O. Lidestri (2004). Use of a water stress index to identify barley genotypes adapted to rainfed and irrigated conditions. Crop Sci., (44): 2127--2137.
[63] Sairam, R. K. and D .C. Saxena, (2000). Oxidative stress and antioxidants in wheat genotypes: Possible mechanism of water stress tolerance. J. Agron. Crop Sci., 184 (1): 55-61.

[64] Sanchez-Blanco, J.; T. Fernandez; A. Morales; A. Morte and J. J. Alarcon (2006). Variation in water stress, gas exchange, and growth in Rasmanrins officinalis plants infected with Glamus deserticola under drought condition .J. Plant Physiol., (161): 675-682.

[65] Schuzendubel, A.; P. Nikolova; C. Rudolf and A. Polle (2002). Cadmium and $\mathrm{H}_{2} \mathrm{O}_{2}$-induced oxidative stress in populous $\mathrm{x}$ canescens roots. Plant Physiol. Biochem., (40); 577-584.

[66] Sibet, T. and T. Birol (2007). Some physiological responses of drought stress in wheat genotypes with different ploidity in turkey. World, J. Agric. Sci. 3 (2): 178-183.

[67] Siddique, M. R. B.; A. Hamid and M. S. Islam (2000). Drought stress effects on water relation of wheat. Bot. Bull., 41 (1): 35-39.

[68] Singh P, S. S. Narayanan, (1993). Biometrical techniques in plant breeding. $1^{\text {st }}$ ed. Kalayani publishers, New Delhi, India.

[69] Sumartini, S.; S. Emy; M. Sri; A. dan (2013). Screening of Cotton line (Gossypium hirsutum 1.) Tolerance to drought at germination stage with PEG6000. Jurnal littri, 3 (19): 139 - 146.

[70] Taiz, L. and E. Zeiger (2006). Plant Physiology, $4^{\text {th }}$ Ed., Sinauer Associates Inc. Publishers, Massachusetts.

[71] Tripathy J.N.; J. Zhang; S. Robin; T.T. Nguyen and H.T. Nguyen (2000). QTLs for cell membrane stability mapped in rice (Oryza sativa L.) under drought stress, Theor. Appl. Genet., (100): 1197-1202.

[72] Waller, R. A. and D. B. Duncan, (1969). A Bayes rule for the symmetric multiple comparison problem, Journal of the American Statistical Association 64, 1484-1504.

[73] Weatherley, P. E., (1950). Studies in the water relation cotton plants: the field measurement of water deficit in leaves. New phytol. (49): 81-87.

[74] Wilkinson, S. and W. J. Davies (2002). ABA-based chemical signalling: the coordination of responses to stress in plants, Plant Cell Environ., (25): 195-210.

[75] Yazar, A., S. M. Sezen, and S. Sesveren, (2002). LEPA and trickle irrigation of cotton in the southeast Anatolia project (GAP) area in Turkey. Agric. Water Manage., 54, 189-203.

[76] Zhong, H and A. Lauchli (1993). Spatial and temporal aspects of growth in the primary root of cotton seedlings: effect of $\mathrm{NaCl}$ and $\mathrm{CaCl}$. J. Exp. Bot., (44): 763-771. 